\title{
20. Developing new standards for internships
}

\author{
Andrew Stewart, Rosemary Owens, Niall \\ O'Higgins and Anne Hewitt
}

\subsection{THE NEED FOR REGULATION}

As the various contributions to this book have highlighted, internships have assumed an increasingly important role in the pathways that promise to lead from education, unemployment or other forms of employment into paid jobs in a wide range of professions and other occupations - especially (but not solely) in developed economies.

On the broadest understanding of the term, and recognizing that it may be called something different in particular locations or contexts (such as a traineeship, placement or practicum), an internship may be undertaken as part of, concurrently with, or after a formal programme of education and training. It may be created and advertised by an organization for its own purposes, or established at the request of an education or training institution, or arranged at the intern's own initiative. It may take place in the intern's home country, or elsewhere. The internship may be sourced directly, or with the assistance of some form of broker or intermediary. It may seek to impart, enhance or offer the opportunity to utilize particular skills or knowledge. It may offer a chance to gain experience of working in a particular organization or sector, or to make contacts that will be valuable to career progression. Alternatively, it may serve simply as a rite of passage that everyone is expected to go through in a particular industry, regardless of how much the work involved actually resembles what the intern may ultimately be hoping or expecting to do if they find paid employment.

In previous literature on internships, as briefly reviewed in Chapters 1 and 2 of this volume, four general and to some extent overlapping concerns have been identified with such arrangements, especially (though not exclusively) when undertaken in the open market; that is, without a connection to a formal programme of education, training or labour market assistance. The first concern is that internships do not always deliver on the promise of 
useful training and skill development. Secondly, and contrary to perception, internships do not necessarily create a bridge from education to paid work, especially when no remuneration is provided. Thirdly, the cost of undertaking unpaid or low-paid internships is likely to be harder to bear for those from less advantaged backgrounds, especially if it is necessary to travel to an expensive location to complete them. Fourthly, the availability of interns as a source of cheap labour creates an incentive for the displacement of paid entry-level jobs and the evasion of minimum wage laws.

To us, the various contributions in this book do nothing to assuage these concerns. Instead, they underscore them. More research is needed to understand how many internships are being undertaken, how they are structured, what role they play, whom they benefit, the extent to which there is any quality assurance in relation to their content, delivery or oversight, and how (if at all) compliance is ensured with any relevant regulation - just to name a few of the questions on which detailed evidence is still lacking in many countries. However, what we believe can be gleaned from the data quoted or presented in Chapters 2-6 of this volume is that structured, formal and, by extension, regulated internships are likely to be more successful in providing an effective bridge to long-term employment, as opposed to a gangplank to long-term work insecurity and income insecurity. Internships vary in their effectiveness but, broadly, the vast majority of analyses contained here and elsewhere which examine their efficacy support this view. When properly conceived and monitored, educational internships, as well as internships undertaken as part of governmental active labour market programmes (ALMPs), are capable of producing better outcomes than unregulated open-market internships. Structure and formality are needed to ensure that interns acquire useful skills and that employers, whether potential or those offering internships themselves, obtain information about the interns and their competencies.

Moreover, while it is evident that educational internships can and often do provide an entry point to subsequent employment, the importance of internships in providing signals to employers - as identified in a number of the early chapters - raises the question, what happens when all or most young people undertake internships? If all young people have been interns, how can participation in an internship provide a signal to employers? Already many young people undertake multiple internships, since one internship appears not to be enough for many employers. The issue of deflation in the signalling value of internships must also be faced. The point also serves to emphasize that the acquisition of work-based competencies does not, of itself, guarantee employment, let alone decent work. Skills development needs to go hand in hand with 
adequate job creation, as has been emphasized repeatedly by the International Labour Organization (ILO) and others. ${ }^{1}$

So, regulation is needed to ensure the quality and effectiveness of internships; but which type of regulation, and by whom? A great deal of the book is given over, either explicitly or implicitly, to the analysis and discussion of this issue, and in this chapter we build upon both our own earlier work in this field and the insights of everyone else who has contributed to this volume to advance some suggestions about the development or refinement of regulatory standards for internships. ${ }^{2}$ We divide our discussion into three main parts, considering first the present and possible future role of international or regional labour standards, then the potential for state (national or subnational) regulation and, finally, the role that non-state actors (such as businesses, trade unions and educational institutions) can and do play. Where relevant, we refer to examples provided or suggestions made in the earlier chapters. We conclude both the chapter and the volume by offering some suggested principles to guide the regulation of internships and respond to the policy challenges they present.

\subsection{INTERNATIONAL OR REGIONAL LABOUR STANDARDS}

By virtue of their subject matter, many of the labour standards adopted by the ILO are particularly relevant to young people. ${ }^{3}$ To date, however, no legal instruments have been adopted by the ILO to 'explicitly guide the regulation of internships/traineeships'. ${ }^{4}$ This is part of a broader gap in relation to training arrangements that involve or include the performance of work. Apprenticeships did once have their own standards, in the form of the Apprenticeship Recommendation, 1939 (No 60), and later Part X of the Vocational Training Recommendation, 1962 (No 117). However, when the

1 To take just one example, see ILO, Global Employment Trends for Youth 2020 (ILO 2020). The point can be found in more or less all of the preceding editions of that publication, as well as in other contributions from the ILO, and in innumerable contributions from other experts and organizations.

2 The chapter reproduces material originally published in an earlier report prepared for the ILO: Andrew Stewart, Rosemary Owens, Anne Hewitt and Irene Nikoloudakis, 'The Regulation of Internships: A Comparative Study' (2018) ILO Employment Policy Department Working Paper No 240, chs 10-11.

3 See eg ILO, 'International Labour Standards Relevant to Youth Employment' (2020), www.ilo.org/global/topics/youth-employment/standards/lang--en/index.htm, accessed 30 March 2021.

4 Ana Jeannet-Milanovic, Niall O'Higgins and Annika Rosin, 'Contractual Arrangements for Young Workers' in Niall O'Higgins (ed), Rising to the Youth Employment Challenge: New Evidence on Key Policy Issues (ILO 2017) 145. 
latter was replaced by the more general Human Resources Development Convention, 1975 (No 142), together with its accompanying Recommendation (No 150), the detailed treatment of apprenticeships disappeared, and was not restored when the Human Resources Development Recommendation, 2004 (No 195) was adopted in place of Recommendation No $150 .^{5}$

This is not to say that interns may not be covered by existing international labour standards. Two instruments mention internships explicitly. Article 2(a) (ii) of the HIV and AIDS Recommendation, 2010 (No 200) expresses an intention to cover 'all workers working under all forms or arrangements, and at all workplaces, including ... those in training, including interns and apprentices'. Article 2(1) of the newest standard, the Violence and Harassment Convention, 2019 (No 190), likewise expresses an intention for the instrument to apply to 'persons in training, including interns and apprentices'.

It is also important to appreciate that many ILO standards, including the core conventions that underpin the ILO's Declaration on Fundamental Principles and Rights at Work (1998), "apply to all "workers" in the broadest sense of the term: that is, they apply irrespective of the kind of contractual arrangement (if any) under which individuals are engaged and, with very limited exceptions, irrespective of the sector of the economy in which they work' ${ }^{7}$ The ILO's supervisory bodies have taken the view, for example, that persons hired under training agreements should have the right to organize, regardless of whether they are 'employed'. 8

However, some ILO conventions are specifically framed to apply only to employment relationships. ${ }^{9}$ Furthermore, even in those instruments which are broad enough to cover interns and other trainees, regardless of their employment status, there is very little specific guidance as to how and to what extent

\footnotetext{
5 As to the extent to which apprenticeships are mentioned in, or covered by, other instruments, see ILO, A Framework for Quality Apprenticeships (ILO 2019) 20-23.

6 These are the Forced Labour Convention, 1930 (No 29), the Freedom of Association and Protection of the Right to Organise Convention, 1948 (No 87), the Right to Organise and Collective Bargaining Convention, 1949 (No 98), the Equal Remuneration Convention, 1951 (No 100), the Abolition of Forced Labour Convention, 1957 (No 105), the Discrimination (Employment and Occupation) Convention, 1958 (No 111), the Minimum Age Convention, 1973 (No 138), and the Worst Forms of Child Labour Convention, 1999 (No 182).

7 Breen Creighton and Shae McCrystal, 'Who is a Worker in International Law?' (2016) 37 Comp Lab L \& Pol J 691, 706.

8 See eg ILO, Freedom of Association: Compilation of Decisions of the Committee on Freedom of Association (6th edn, ILO 2018) para 394.

9 Creighton and McCrystal (n 7) 723-4.
} 
their provisions should apply to these workers. An exception is article 6 of the Minimum Age Convention, 1973 (No 138), which provides as follows:

This Convention does not apply to work done by children and young persons in schools for general, vocational or technical education or in other training institutions, or to work done by persons at least 14 years of age in undertakings, where such work is carried out in accordance with conditions prescribed by the competent authority, after consultation with the organisations of employers and workers concerned, where such exist, and is an integral part of:

(a) a course of education or training for which a school or training institution is primarily responsible;

(b) a programme of training mainly or entirely in an undertaking, which programme has been approved by the competent authority; or

(c) a programme of guidance or orientation designed to facilitate the choice of an occupation or of a line of training.

Ostensibly, these provisions appear to suggest that work undertaken in those circumstances should somehow be outside regulatory oversight - an assumption that is challenged by many of the contributors to this volume, and an issue to which we return in the final section of this chapter.

Happily, there may soon be an opportunity for the International Labour Conference to consider whether specific standards should be adopted for the regulation of internships and other training arrangements. As noted in the opening chapters of this volume, the ILO has released a report about the formulation of a possible new convention and/or recommendation. ${ }^{10}$ This would not just fill the gap in the regulation of apprenticeships left by the human resources development instruments, but address in a more limited but still significant way the regulation of 'traineeships'. That term is defined as including 'internships' and extending to 'any form of on-the-job learning, which enables a person (the "trainee") to acquire work experience with a view to enhancing their employability'. ${ }^{11}$ The questionnaire to member states that accompanies the report specifically contemplates the possibility of requirements for a written traineeship agreement, adequate remuneration, controls on working hours, paid holidays, sick leave, accident compensation and other benefits for interns, as well as the same protections and training as for others in the workplace in relation to health and safety or discrimination, violence and harassment. $^{12}$

The original plan had called for a 'double discussion' of any possible new standard(s) at the 2021 and 2022 sessions of the International Labour

ILO, A Framework for Quality Apprenticeships (n 5).

Ibid 80.

12 Ibid $97-8$. 
Conference. ${ }^{13}$ With COVID-19 being responsible for the deferral of the 2020 session, that timeframe has now been revised. Member States have been given until 31 March 2021 to respond to the questionnaire. ${ }^{14}$ If there is no further delay, this suggests that a new instrument or instruments could potentially be adopted in 2023.

At a regional level, there is already one example of supra-national standards concerning internships, the Quality Framework for Traineeships promulgated in 2014 by the Council of the European Union (EU). ${ }^{15}$ The framework is focused primarily on open-market traineeships; it does not cover 'work experience placements that are part of curricula of formal education or vocational education and training', nor traineeships whose content is regulated under national law and which must be completed to enter a particular profession, such as medicine or architecture. ${ }^{16}$ This reflects the finding from an earlier review, which revealed that most existing laws and regulations within the EU relate specifically to traineeships undertaken as part of formal education and training courses, or ALMPs, rather than the open-market arrangements identified as being in the greatest need of attention. ${ }^{17}$

The framework requires a prior written agreement for traineeships setting out (among other things) the educational objectives and duration of the arrangement, working conditions, whether the trainee is to be remunerated or compensated, and the parties' rights and obligations. It seeks to ensure that, where applicable, any limits set by national or EU laws on working time and rest periods are respected, together with holiday entitlements, and encourages traineeship providers to clarify whether they offer health and accident insurance, as well as sick leave. The framework also requires traineeships to have a reasonable duration that will not generally exceed six months, clarifies the circumstances in which a traineeship may be extended or renewed, and encourages the parties to make clear the circumstances under which the arrangement may be terminated. It encourages a supervisor to be designated and advocates the recognition, assessment and certification of the knowledge, skills and competences acquired during a traineeship. It also promotes transparency, by

13 Ibid 3.

14 ILO, Minutes of the 338th Session of the Governing Body of the International Labour Office, Governing Body, 338th Session, Geneva, GB.338/PV(Rev.4) (28 August 2020) para 353(g).

15 Council Recommendation of 10 March 2014 on a Quality Framework for Traineeships [2014] OJ C88/1.

16 Ibid, preamble, para 28.

17 Kari P Hadjivassiliou, Emanuela Carta, Tom Higgins, Catherine Rickard, Suzanne Ter-Minassian, Flavia Pesce and others, Study on a Comprehensive Overview on Traineeship Arrangements in Member States: Final Synthesis Report (European Union 2012). 
encouraging advertisements and other information to specify both the terms and conditions of a traineeship, and the number of trainees typically recruited into ongoing employment.

It is easy to understand why standards of this kind should be considered appropriate for at least some types of training. However, aside from the need to determine at what point a work experience arrangement becomes sufficiently substantial to warrant this level of formality and prescription, the EU framework leaves unresolved the issue of whether, and to what extent, interns should also enjoy the protection of general labour or social laws. It encourages any applicable rules to be observed, but does not say which rules do or should apply. Arguably, this is a major deficiency. As Annika Rosin discusses in Chapter 17 of this volume, it is possible that the EU's Charter of Fundamental Rights could be used to improve the protection of interns. However, that depends on a genuinely broad interpretation of the concept of a 'worker' being adopted, something which cannot be assumed.

\subsection{STATE REGULATION}

At a national or subnational level, at least five different approaches to state regulation of internships can be identified - where any regulation exists at all. ${ }^{18}$ These are:

1. Specific regulation of the use or content of internships.

2. Regulation by inclusion, that is, expressly bringing internships within the operation of labour or social laws, either by defining them as employment or extending employment rights to certain training arrangements.

3. Regulation by exclusion, that is, expressly exempting internships from the operation of labour or social laws.

4. Strategic enforcement of labour or social laws by the state, even in the absence of any specific extension or exclusion.

5. Systematic use by the state of soft law, such as codes of practice, to influence the use and content of internships in government and/or non-government organizations.

In a comparative study of 13 countries undertaken for the ILO and published in 2018, ${ }^{19}$ four (Argentina, Brazil, France and Romania) were found to have introduced specific legislation to regulate internships. Significantly, the first three of those have effectively outlawed open-market internships, by requiring

18 Rosemary Owens and Andrew Stewart, 'Regulating for Decent Work Experience: Meeting the Challenge of the Rise of the Intern' (2016) 155 Int Lab Rev 679, 688.

19 Stewart and others (n 2). 
a tripartite agreement involving the intern, the host organization and an educational institution. The French approach in particular is singled out as being worthy of consideration by several contributors to this book, including Paula McDonald, Andrew Stewart and Damian Oliver in Chapter 5 and Anne Hewitt in Chapter 13.

In many of the other countries covered by the 2018 study, including Germany (considered in more detail by Bernd Waas in Chapter 7 of this volume), interns have expressly been brought within the coverage of particular labour or social laws. However, it is just as common for ALMP or (especially) educational internships to be excluded from the operation of such laws, in the same fashion as the EU Quality Framework for Traineeships. Neither is much typically done to ensure that these arrangements attract the type of governance or quality assurance that is often assumed to follow from the involvement of educational institutions or public employment services, a point emphasized by Anne Hewitt (Chapter 13) and Irene Nikoloudakis (Chapter 14). As Alexandre de le Court and Julia López López note too, in Chapters 16 and 19 respectively, accepting the legality of unpaid or low-paid internships can segment the labour market and institutionalize discrimination against the young.

The 2018 study also found that in many countries it remains an open question whether internships, especially but not solely those arranged in the open market, are covered by general labour laws that make no explicit reference to these arrangements. The answer would generally depend on a court, tribunal or government agency determining whether an intern falls into the often undefined category of 'employee' or subordinate worker. In some jurisdictions, the number of cases testing this issue has risen in proportion both to the use of internships and to the critical attention devoted to them by government agencies, academics, the media and intern groups. Australia appears to be the only country in which a government agency (the Fair Work Ombudsman) has systematically and publicly pursued sanctions against businesses or other organizations involved in the use of potentially unlawful internships. ${ }^{20}$ However, even there, as Rosemary Owens explains in Chapter 11 of this volume, the status of many interns cannot be taken as settled.

The same uncertainty can be found in other common law systems, as Wil Hunt and Charikleia Tzanakou (Chapter 6), James Brudney (Chapter 10) and Amir Paz-Fuchs (Chapter 15) demonstrate in their respective contributions. Brudney's discussion of the USA represents a particularly cautionary tale, in the way in which coverage of the Fair Labor Standards Act, with its deliberately broad definition of 'employ', has been progressively eroded by

20 See eg Fair Work Ombudsman v Crocmedia Pty Ltd [2015] FCCA 140; Fair Work Ombudsman v AIMG BQ Pty Ltd [2016] FCCA 1024. 
the judiciary. ${ }^{21}$ Indeed, even where legislative regimes seem broad enough to cover interns, as Alysia Blackham notes in discussing equality laws in Chapter 18 , the cost and uncertainty of enforcement proceedings may mean they are not considered worth the risk.

\subsection{THE ROLE OF NON-STATE REGULATORY ACTORS}

There are various ways in which internships can be - and are in practice - regulated, other than by the state. Organizations that host or engage interns will often develop their own rules and processes (whether formal or informal) for selecting those who will participate, for designing and supervising whatever tasks interns are invited or required to perform, and for ensuring interns adhere to the organization's policies and procedures. Educational institutions are also likely to have internally generated rules that govern the administration and assessment of educational placements, as discussed, for instance, by Joanna Howe and Anne Hewitt in Chapters 12 and 13, respectively.

At a broader level, other bodies or groups may seek to influence the use, content or treatment of internships. In many countries, private codes or guidelines have been put forward by peak bodies or industry groups. In the UK, for instance, the National Council of Voluntary Organisations has developed a guide for internships in the voluntary sector, emphasizing the difference between employment and 'true' volunteering, canvassing the arguments about the appropriateness of taking on volunteer interns, and suggesting 'principles of good practice'. ${ }^{22}$ Pressure groups representing young people have also been very active in this space. For example, the European Youth Forum has developed an Employers' Guide to Quality Internships which has been endorsed by a number of major companies. ${ }^{23}$

Trade unions, too, may be involved in helping to set minimum wages and other conditions for interns, through collective bargaining. It has been reported that collective agreements play a significant role in regulating traineeships (at least of particular kinds) in many European countries. ${ }^{24}$ Examples of this prac-

$21 \quad$ See eg Glatt v Fox Searchlight Pictures, Inc 811 F 3d 528 (2016).

22 National Council of Voluntary Organisations, Voluntary Internships in the Voluntary Sector: Review and Guidance (National Council of Voluntary Organisations 2015).

23 See European Youth Forum, European Quality Charter on Internships and Apprenticeships, www.youthforum.org/quality-internships/, accessed 30 March 2021.

${ }^{24}$ Hadjivassiliou and others (n 17) 62, 95-8; European Commission, 'Applying the Quality Framework for Traineeships' (2016) European Commission Staff Working Document 324, 6 . 
tice from Germany and Sweden are provided by both Bernd Waas in Chapter 7, and Jenny Julén Votinius and Mia Rönnmar in Chapter 9. The latter in particular highlight the positive influence of the 'social partners' (trade unions and employer associations) in helping to ameliorate some of the negative aspects of internships commonly identified in other jurisdictions. However, even in Sweden, as they note, there are signs that the role accorded to collective bargaining is under challenge. At a time when union density and collective agreement coverage are in decline in many parts of the developed world, ${ }^{25}$ it is hard to envisage the social partners coming to play a prominent part in regulating internships in countries where they do not already do so. Even in countries with a strong tradition of social dialogue, there may still be questions about whether the laws and processes governing collective bargaining can apply to interns who are not regarded as employees. ${ }^{26}$

\subsection{SIX PRINCIPLES FOR THE REGULATION OF INTERNSHIPS}

As Paula McDonald, Andrew Stewart and Damian Oliver note in Chapter 5, it is hard to imagine even unpaid internships being banned in the foreseeable future; but this is not to say that they cannot or should not be appropriately regulated. The central policy challenge which internships present is to balance the positive contribution they can potentially make with the reality that they may represent a form of precarious work. ${ }^{27}$ In this concluding section, and building on previous work, ${ }^{28}$ we suggest six principles to guide the design of new laws for this purpose, or indeed the framing of new international standards.

1. Certain types of internship, however they are labelled by the parties, should attract the same entitlements and protections as an 'ordinary' employment relationship. The possibility that internships may, if misused, constitute 'disguised employment relationships' has recently been noted by the ILO's Committee of Experts on the Application of Conventions

25 See OECD (Organisation for Economic Co-operation and Development), Negotiating Our Way Up: Collective Bargaining in a Changing World of Work (OECD 2019) 33-48.

26 See eg Annika Rosin, 'Precariousness of Trainees Working in the Framework of a Traineeship Agreement' (2016) 32 Int J Comp Lab L \& Indust Rel 131, 147-51; see also the same author's discussion in Chapter 17 of this volume on the applicability of the collective rights recognized in the EU's Charter of Fundamental Rights.

${ }_{27}$ Joseph F Turcotte, Leslie Nicholls and Lisa Philipps, Maximising Opportunity, Mitigating Risk: Aligning Law, Policy and Practice to Strengthen Work-Integrated Learning in Ontario (Higher Education Quality Council of Ontario 2016) 5.

28 Owens and Stewart (n 18) 704-5. 
and Recommendations. ${ }^{29}$ As Rosemary Owens notes in Chapter 11, it is important that the determination of employment status involves a robust assessment which eschews both subjectivity (that is, the parties' own statements about the nature of their relationship) and formalism (such as an assumption that because a process for gaining practical experience is part of a structured course of study or training it should not be regarded as 'work'). It may well be appropriate to exclude internships from being treated as employment relationships, and thus as subject to general labour laws, if they are part of a well-regulated scheme of education and training. Otherwise, where productive work is undertaken as part of an internship for a business or organization, the mere fact that the interns have 'volunteered' their services or are gaining useful experience or contacts should not disqualify them from labour protections.

2. Even if a particular type of internship should not attract the operation of specific employment standards, this should not dictate its exclusion from all forms of labour or social regulation. We see no reason why laws dealing with matters such as work safety, accident compensation, discrimination and harassment should not apply to interns while they are at work, even when undertaking a placement as part of an educational course or an ALMP. Arguably, the values of safety and equality at work should be seen as objectives that apply to all forms of work, whether paid or unpaid, and whether or not undertaken as part of education or training. The same should be true of the other 'core' standards recognized as part of the ILO's 1998 Declaration on Fundamental Principles and Rights at Work, including freedom of association and the right to engage in collective bargaining.

3. Even in the case of educational or ALMP internships that are excluded from the operation of particular employment standards, such as minimum wages, it may be appropriate to establish modified entitlements or protections, especially for programmes that extend beyond a particular duration. This is something that some countries already do. In France, for example, the length of internships is capped at six months, and for any arrangement exceeding two months the intern is entitled to compensation (although this is expressly stated not to be a salary). Interns are

29 ILO, Promoting Employment and Decent Work in a Changing Landscape, Report of the Committee of Experts on the Application of Conventions and Recommendations, Report III (B), International Labour Conference, 109th Session, International Labour Office 202092. 
also granted a range of other workplace protections, including limits on daily and weekly working hours. ${ }^{30}$ However, if interns are to be entitled to something less than the regular minimum wage, this should only be the case if they are receiving 'actual training during working hours', with the 'quantity and quality of the work performed' remaining a decisive factor in determining what they are paid. ${ }^{31}$

4. There should be minimum standards for the documentation of educational or ALMP placements, their duration, hours of work, requirements for specific learning outcomes to be achieved and the need to monitor what is happening at the relevant workplace. As a number of contributors to this book have argued, it should not simply be assumed that the mere involvement of an educational institution or public employment service will be sufficient to assure these objectives. Once again, France provides a useful model here, at least in relation to educational arrangements. The agreement that must exist between intern, host organization and educational institution must state the activities the intern will undertake and the skills they will develop. In addition, the intern must be supervised by both the institution and the host; and, in order to ensure effective supervision, there are strict limitations imposed on the numbers of interns that supervisors can oversee. ${ }^{32}$ This approach recognizes that it may be just as important to structure and appropriately regulate the learning component of an internship as the working component. ${ }^{33}$

5. Agencies responsible for the enforcement of labour standards and other social protections should be aware of the particular issues associated with internships, provide information and assistance to interns, educational institutions and organizations hosting internships, and take appropriate action against exploitative and unlawful arrangements. As previously noted, this is something that Australia's Fair Work Ombudsman has done over recent years, but seems to be far less true in other countries. ${ }^{34}$ In Chapter 10 of this book, James Brudney shows what an enhanced

\footnotetext{
30 Code de l'éducation, arts L124-5, L124-6.

31 Minimum Wage Systems: General Survey of the Reports on the Minimum Wage Fixing Convention, 1970 (No 131) and the Minimum Wage Fixing Recommendation, 1970 (No 135) Report of the Committee of Experts on the Application of Conventions and Recommendations, Report III (1B), International Labour Conference, 103rd Session, International Labour Office 2014 para 188.

32 Code de l'éducation, arts D124-3, D124-4(4), L124-2(2)-(3), L124-9, R124-13.

33 Jeannet-Milanovic and others (n 4) 161.

34 Stewart and others (n 2) 41-3.
} 
approach by the labour inspectorate could look like in the USA. Among other things, he highlights the importance of clear administrative guidance to employers wishing to sponsor interns, close cooperation with educational institutions to ensure they have in place meaningful protections for student interns, and prohibitions on the displacement of regular employees. Similarly, in her consideration of equality laws in Chapter 18, Alysia Blackham calls for an increased focus on enforcement, to ensure interns are assisted and encouraged to assert their rights.

6. Efforts should be made to improve access to good quality internships for those from disadvantaged backgrounds. Mahlatse Maake-Malatji's contribution to this volume, Chapter 8, reminds us that securing decent work experience is seldom as simple as just attending to the scope of labour regulation; it demands action and reforms that take account of the broader social, economic and cultural contexts. This is also stressed by Charikleia Tzanakou, Luca Cattani, Daria Luchinskaya and Giulio Pedrini in Chapter 4, where they write of the importance of ensuring that recruitment for internships does not simply reproduce structured inequalities in the labour market.

Given the benefits that internships may offer in relation to employability, but the potential barriers they may also create (or raise) for disadvantaged students, graduates or job seekers, it seems to us that addressing this issue should be an important component of any effective regulatory regime. Banning unpaid internships in the open market would be a step forward in this respect. However, there is also much to be recommended for reducing the opportunity cost for those from lower socio-economic groups in undertaking work experience as part of educational programmes, and 'improving provision of information to students and early graduates about the likelihood of different outcomes from internships in key fields' ${ }^{35}$ In this respect, we see great value in a set of proposals put forward for British higher education. ${ }^{36}$ If broadened from the specific context in which they were originally advanced, they could include ensuring that educational institutions prioritize disadvantaged students in brokering work placements; overcoming geographical barriers by funding 'residential internship' opportunities for young people from remote areas;

35 Angus Holford, 'Access to and Returns from Unpaid Graduate Internships' (2017) ISER Working Paper Series 2017-07, 30, https://www.iser.essex.ac.uk/research/ publications/working-papers/iser/2017-07, accessed 30 March 2021.

36 Carys Roberts, The Inbetweeners: The New Role of Internships in the Graduate Labour Market (Institute for Public Policy Research 2017), https://www.ippr.org/ publications/the-inbetweeners, accessed 30 March 2021. 
using a training levy to help employers offer high-quality placements; and banning placements of longer than a certain duration, unless they involve paid employment.

There is no single right way to regulate internships, and regulation cannot in any event solve every problem in the burgeoning field of work-based learning. However, if work experience is not simply to be a charter for exploitation, and if the promise of internships as an effective bridge from education to work is to be truly realized for more than just a privileged few, the principles we have outlined seem to us to provide a worthwhile starting point in meeting one of the great policy challenges in the world of work. 